\title{
REVIEWS, OF BOOKS.
}

Diseasis of the Anus, Rectum, and Pelvic Colon. By James P. Tutree, A.M., M.D., Professor of Rectal Surgery in the New York Polyclinic Medical School. New York: D. Appleton \& Co., 1903.

This work appears to be onc of the most complete, exhaustive, and thorough presented for the aid and instruction of the rectal specialist.

The chapters on Embryology, Anatomy, Physiology, and Malformations are full and accurate; that on Examination and Diagnosis being replete witl valuable suggestions.

The author's landling of the subjeets of Proctitis, and Catarrhal Diseases of the Sigmoid and Colon, leaves little, to be desired.

The chapter on '[ubereulosis of Reetum and Colon seems to the writer the most complete to be found in any modern work of the kincl. Allingham, Kelsej, and Mathews give the subject but scant mention. The sane is true of Gant in his recent work.

In Fissure in Ano the author describes a method of treatment, by repeated applications of pure iclithyol following insufflation of orthoform, by which incans he claims a large pereentage of cures in uncomplicated cases. This method scems worthy of fuller trial.

In operative procedure lie indicates three methods,--dilatation, incision, and excision; and he seems, in the main, to favor incision, bccausc, as claimed, it is more certain to curc, and obviates the neessity of a general anestlietic. In this he agrees with Kelsey. The writer would dissent from this conclusion, agreeing most decicledly with Mathews in favoring dilatation, because the operation is less formidable; the relief, in nearly all cases, very prompt; the healing specdy, and the paticnt scldom laid up more 
than one day, which is a great consideration. If the sentinel pile is removed, and overlanging edges paired if they exist, failure seldom results. The matter of gencral anasthesia may be a point against divulsion. The writer has met this by using in over 800 cases nitrous oxide, which has answered the purpose admirably, and which the patients take with but slight inconvenienee.

On the other hand, ineision, unless deep enough to divicle the sphineter, often fails, Dupuytren, Curling, and Copeland to the contrary notwithstanding, and when thus deep, makes a wound diffienlt to keep aseptic, which heals slowly, and in most eases means detention from avocation for some time.

The author's treatment of the subjects of Perianal and Pcrireetal Abseesses and Fistula is very full and explieit. The delineations of teclnnique, methods of opcration, and subsequent treatment, are admirable; and the indications pointed ont in favor of excision with immediate suturing, in seleeted eases of fistula, worthy of fullest consideration.

In the matter of treatment of liemorrhoids, this work may almost be said to inark a new departnre, in that the anthor, differing from Allinghan, Mathews, Gant, and from the present attitude of Kelsey, gives his unqualified endorsement to the usefulness of the injection method for the treatment of ancomplicated cases of interual hamorrhoids.

His dissent from the almost universal clorus of condemmation by the standard authors is marked by a careful discrimination between the two systems in vogue, i.e., the one which injects strong solutions in large quantities, thus eatsing sloughing of the tumors, and the one which uses small quantities of weak solutions, producing mild inflammation, incluration, and fual atrophy of the pile, without uleeration or sloughing.

The former he emplatically, and justly, condemus; the latter he endorses. Yet this first method is the one generally inclicated and described by the authorities as the injeetion method, and its evil results pointed out. 
For instance, Gint, in his recent work, gives as an illustrative case a patieut who would not submit to an operation, whom he treated thus. Four tumors were injected at once with a moderately strong carbolic solution, teu minins to cach tumor. On the tenth day, two tumors remaining were well treated in the same manner. Result, great paiu, inflanmation, sloughing, and abscess.

A practitioner experienced in this method would expect nothing else. The error is in the excess of fluid injected, overfilling the tumors, and extending the inflammation to the surrounding cellular tissuc, and in treating too many tumors at once.

The experience of the writer, in a large number of cases treated by the milder method, leads him to almost adopt the identical conclusions of Professor Tuttle.

This method is not to be heralded as a universal substitute for the more radical and effective operations of ligature, clamp, and eautery; but there are multitudes of enses, when wisely selected, in which it will give very satisfaetory cures, with a mininum of ineonvenicuee, and no detention from ordinary duties.

The attitude of the profession must eliange in this regard, and this work will mark a step in the right direction.

'The author's eriticism of the modification of Whitehend's operation, introduced by Pratt, of Chicago, seems fully justified by several cases which have eome under observation, where the results were very unsatisfactory.

The criticism of the Allingham and Vanburen method of caluterizing the mass in prolapse of the rectum with nitric acid or ictual cautery is noted with satisfaction, as also the recommendation of the renoval of sections of the membrane by clamp and cautery, as giving better guarantec of success.

The chapters on Malignant Neoplasms and Excision of the Rectum are replete with valuable information; and the large number of eases gatliered and tabulated very instructive. The facts point to, and seem to bear out, the conclusions of the author, that early cxcision of the rectum, in judiciously seleeted cases, 
not only offers a hope of prolonged life, but in a small per cent. of thesc unfortunatc cases does give promisc of permanent eurc.

To counterbalance this, lowever, is the ominous death-ratc of about 20 per cent., which thic best ascptic teclınique has not becn able to materially reduce. But when we eonsider that the lives thus shortened were doomed withont surgical interferencc, the balance still scems to bc in favor of the author's conclusion, when action is tempcred with wise conscrvatism.

The author's treatment of colostomy, his careful differcntiation of methods, and the conditions requiring the temporary or permanent operations are admirablc.

It would secm that the limitations he suggests as to the usefulness of Colostomy in malignant cases of the reetum arc justified; and that thic attitude of eertain surgcons, who seem to be ready to perform Colostomy on nearly all eases whcre exeision is not admissiblc, in no sensc commends itself to the eonservative inind.

J. Russell Taber.

GYNAcology. A Text-Book for Students and a Guide for Practitioners. By Wittiam R. PRYoR, M.D., Professor of Gynxcology, New York Polyclinic Medical Sclool, etc. Oetavo, $373 \mathrm{pp}$, I $\sigma_{3}$ illustrations. New York: D. Appleton \& Co.

The author of this work has given us a concise treatisc upon those subjects whieh are strictly gyniecological, and which are commonly met with in private practice. Feiv rare diseases arc described or illustratcd, and no space is sacrificed to bibliography, mintitc anatomy or microscopy which are of little interest to the general readcr. The revicwer can but congratulate Dr. Pryor on his sclections and upon the general arrangement of this readable book.

Dr. Pryor's large expericuce as a teacher, his power to errthuse his auditors, and his positivencss, carry conviction, and 
make the book of particular value as a guide to the general practitioner, who will find many excellent and explicit suggestions in the various elapters.

The work is divided into two parts. In the first, those diseases peculiar to women are clearly and concisely described, and the text elucidated with illustrations of more than ordinary merit. The second part of the book is devoted to a description of the various gynxeological operations, and a consideration of the indications and the contraindications for the same. The details of teclunique in both local and operative treatment of the various pelvic disorders are specially dwelt upon.

The clapters on pelvie inflammations are noteworthy, gonococcic and septic infections have received mucl attention, and the general subject of peritonitis is dealt with in such a thorough and practical manner that both student and surgeon will find it interesting and suggestive.

The seetions on discases of the urethra and bladder are replete with praetieal suggestions as to diagnosis and treatment, and merit commendation. The surgery of the perinem and cervix are well described, and the operations on these structures made clear by numerous, well-executed illnstrations. One can hardly sec reason for the author's strong advocacy of silver wire in plastic work, when cliromic, tendon, and silkworm gut will give the desired results.

The clapters on ovarian and nterine neoplasms and cancer are interesting; these subjects are thoroughly, though not exhaustively, considered; the pathology of the latter discase is well illustrated, and the indications and limitations for operative intervention are definite.

The author's ideas on drainage after abdominal operation, and his general rules for its employment or avoidance, are based on sound logie, and will be read ivith profit.

Dr. Pryor we find at his best in his description of vaginal hysterectony with hemisection of the uterus for pelvie suppura- 
tion; this original cliapter contains much that will be helpful to every gynecological surgeon. The pages on the preparation of the patient for major operations and her post-operative management are of special value to the oceasional operator, who is in need of explieit direetions as to the proper care of his case.

There can be little doubt that the author favors vaginal operations when intrapelvie conclitions make the vaginal route possible; however, he differentiates with skill the conclitions to which it is applicable, and discusses the advantages of the abdominal operation without bias.

The work as a whole is interesting, original, seientific, and will be found to be a most practical aid to the student as well as to the finished surgeon.

$$
\text { Johin O. Polak. . }
$$

Diseases of tife EAr. A Text-Book for Practitioners and Stilderts of Medicine. By Edwaro Brndford Dencit, Pir.B., M.D., Professor of Otology in the University and Bellevue Hospital Medical College. Third Edition, Revised. New York: D. Appleton \& Co.

This treatise has already gained for itself a plaee of honor among the many books that have recently been appearing in this special field of work. The' issue of a new and revised edition (third) of it speaks well for its eharaeter. The eonstituency for such a work is growing, but the work must have intrinsic worth to loold the constitueney. This we coneede it lias.

The author aclopts a style all his own: we are not often impressed with its like. It has a certain dignity of eadence, an $e . r$ cathedra quality of utterance, that reminds one of the lecturer proceeding with measured sentenee and repelling querulous interruption.

This is impressive and takes with the general reader, who likes what is authoritative and seldom eares to question on his own initiative. Sueh a work does good where a fair and honest 
quantum of responsibility is felt in such an attitude as we believe is here manifest. The revisions and additions are evidence of this scuse. But in accordance with the style above noted is the ever-prescut sense of remoteness both in the original and in the revision. The author does not enter largely into discussion or detail. His treatment is curt and summary, but measurably complete.

Heber Nelson Hoople.

Infectrous Diseases: Their Etiology, Diagnosis, and Treatment. By G. H. Roger, Professor Extraordinary in the Faculty of Medicine of Paris, etc. Translated by M. S. Gabriel, M.D., New York. Oetavo, 864 pages. Philadelphia and New York: Lea Brothers \& Co., I903.

Tlıe time is ripe for the making of this book. Sone one was needed to condense and systematize up to date onr knowledge about Infeetious Diseases. This the author las done in lis own way. Iis qualifications were adequate. Being a master in the biologieal laboratory, and laving exceptional opportunities as a lospital clinician, lie combined in himself the indispensable prerequisites for this task. The task was prodigious,-so much literature to be read, so muclı to be done in the laboratory, so much to be scen at the bedside, and withal so much of the scientific luabit of mind to properly marslaal the vast amount of material into a homogencous volume. The author las measurably succecded. He has written well. He has nuade his book interesting and useful. Witl enthusiasm and eloruence he has made a scientific book pleasing. He las practically given us a treatise on medicine from a new view-point. He asscrts things: he is nothing, if not positive. These are needed and valuable qualities in a gool book. Besides, in the main, he succeeds in his aim and gets everything into one volıme. We qualify his suceess, because of certain defects which we shall point out. But, first, we commend especially the chapter on Suppuration, valuable alike to the surgeon and the physician. The author is discriminating in his 
elhapter on Septicamia and Pyæmia. Some'of the author's statements are delightful in their very simplieity. In the ehapter on Fever lie states fever is "essentially elaracterized by an exaggeration of the ehemieal proeesses oecurring in the organism," and "the fever of infections is a reaction of the organism against nierobic toxiıs." Though the author has elear vision and logieal acumen, we fear he is not always on his guard. At least we eannot leap with him to the eonelusion that "all nervous affections (save family ard hereditary disease) are eaused by some infection or intoxication," beeausc, as he says, inoenlations with more or less virulent germs "in animals have produeed a series of nervous affections and notably myelitis." We find him elaiming, in a case of Landry's paralysis, where death oceurred in a paroxysm of dyspncea after paralysis of the feet and where the histologieal exninination of the limbar enlargentent of the eord revealed altered nerve elements in the anterior horns withont mierobie foci (tlough the blood furnished pure cultures of the pneumococens), that therefore the ascending paralysis was "due to pnetunocoecic infection." As a rule, the logic is more steady and reliable.

The sliort chapter on Mechanism of Immunity and Predisposition is one of the best. "The agglutinating reaction is speeific. It is exercised only upon the element against which the animal reacts." "The modifiention of the fluids explains all acquired immunity." Statements like these are ellarming: they are ensily aceepted beeause so firmly stated, saving the reader from need of rebellious thought. The author is fully eognizant of the complexity of the problems, deals with them intelligently, and presents the most plausible ease the faets afford.

Congenital Infeetions and Feredity and the Therapenties of Infeetious Diseases are both well-written and interesting seetions and share our commendations. But in muel of the rest of the book, and to some extent in these ehapters, the author writes too much. A working knowledge is desirable; exhaustive analysis is not practicable in narrow limits. Therefore it is an error to attempt it, causing the style at times to become prolix and verbose 
where for the most part it is delightfully terse and vigorous. The result is we have a big book on our hands, where one half the size would have answered better. In a word, the laboratory is too much in evidence here. In fact, it would be a great desideratum to have all the author's knowledge that is available in kernels of truth and wisdom gathered into small space so as to stand out boldly and impressively; for the book is rich in good meat if we could but easily get at it to eat.

We can lay no serious charge at the door of the translator, though he has strangely retained the French word "recidive" in the text. The publislicrs' part also ltas been well done. But we lave a comment to make on this book in common with others emanating from European sourees. In the first plaee, it contains a stingy index. Of all books that necded a liberal index, even a cross-index, this one most. In the second place, though we lave eredited the author with wide reading, generously acknowledged in his text, yet, like so many of his continental confrc̀res, he alunost eompletely ignores work and literature of England and Auserica. Not once is there mention even of yellow fover; and, though many names are inciuded in referenecs to the work of Laveran, Patriek Manson and Ronald Ross are omitted. The title of this book is on the faee of it a claim to comprehensiveness. All Amerieans will note with regret the failure to cite American rescarches in yellow fever and the name of our lamented Reed in its heroie relation to the study of that clire infection.

\section{Heber Nelson Hoople.}

Sochal Diseases and Marriagi:. By Prince A. Morrow, A.M., M.D., Emcritus Professor of Genito-Urinary Disenses in the University and Bellevue Hospital Medical College of New York. Octavo, $390 \mathrm{pp}$. New York and Philadelphia: Lea Brothers \& Co., 1904.

It is the object of this work to set forth the dangers introdueed by venercal diseases into marriage, and to indicate the most 
effcctive uncans to prevent these dangers or to linit and circunscribe their spread. In pursuance of his plan, Dr. Morrow has divided his book into three parts, the first of which deals with Gonorrhœe and Marriage, the second with Syphilis and Marriage, the third with matters pertaining to Social Prophylaxis. The large part which gonorrlıca in recent decades has come to be recognized as playing is suggested by the fact that the section of this book devoted to the consideration of this part of the subject is the largest of the three. 'There is nothing sensational nor liysterical in the author's methorls. His points are clearly made, and his statements of fact are in full accord with present knowledge. It is a book worth reading upon a subject that ought to be plainly and fully treated. Any intelligent aduit wonld be bencfited by its perusal, and it is not likcly that its circulation will be confined to physicians.

Lewis S. Pilciter.

\section{TO CONTRIBUTORS AND SUBSCRIBERS.}

All Contributions for Publication, Books for Review, and Exclianges should be sent to the Editorial Ofice, 386 Grand Ave., Brooklyn, N. Y.

Remiltance for Subscriptions and Advertising and all business communications should be addressed to the

ANNALS OF SURGERY, 227-23ı Sonth Sixth Street, Philadelphia. 